\title{
OPEN Photochemical efficiency correlated with candidate gene expression promote coffee drought tolerance
}

\author{
Meline de Oliveira Santos ${ }^{1}$, Larissa Sousa Coelho ${ }^{2}$, Gladyston Rodrigues Carvalho ${ }^{3}$, \\ Cesar Elias Botelho ${ }^{3}$, Luana Ferreira Torres², Diego Júnior Martins Vilela ${ }^{5}$, \\ Alan Carvalho Andrade ${ }^{4} \&$ Vânia Aparecida Silva ${ }^{3 凶}$
}

The aim of this study was to identify the correlation between photochemical efficiency and candidate genes expression to elucidate the drought tolerance mechanisms in coffee progenies (Icatu Vermelho IAC 3851-2 × Catimor UFV 1602-215) previously identified as tolerant in field conditions. Four progenies $(2,5,12$ and 15$)$ were evaluated under water-deficit conditions (water deficit imposed 8 months after transplanting seedlings to the pots) and under irrigated system. Evaluations of physiological parameters and expression of candidate genes for drought tolerance were performed. Progeny 5 showed capacity to maintain water potential, which contributed to lower qP variation between irrigated and deficit conditions. However, the increases of qN and NPQ in response to stress indicate that this progeny is photochemically responsive to small variations of $\Psi$ am protecting the photosystem and maintaining qP. Data obtained for progeny 12 indicated a lower water status maintenance capacity, but with increased qN and NPQ providing maintenance of the $\Phi$ PSII and ETR parameters. A PCA analysis revealed that the genes coding regulatory proteins, ABA-synthesis, cellular protectors, isoforms of ascorbate peroxidase clearly displayed a major response to drought stress and discriminated the progenies 5 and 12 which showed a better photochemical response. The genes CaMYB1, CaERF017, CaEDR2, CaNCED, CaAPX1, CaAPX5, CaGolS3, CaDHN1 and CaPYL8a were up-regulated in the arabica coffee progenies with greater photochemical efficiency under deficit and therefore contributing to efficiency of the photosynthesis in drought tolerant progenies.

Coffee is a tropical tree species being one of the most traded commodities worldwide. Coffee production represents an extremely important economic factor for both consumer countries and producers, where it represents the basis of income for a large number of small and medium farmers. Coffea arabica L. and Coffea canephora P. are the two species commercially relevant with approximately $60 \%$ and $40 \%$ of global production, respectively ${ }^{1}$. Climate change is expected to have a negative impact on production, with a consequent economic and social impact in countries. In Brazil, the largest coffee producer, drought represents a major constraint for coffee production ${ }^{2}$. Variations in the climate characterized by episodes of drought or irregular rainfall distribution have been observed frequently in recent years, especially those that occurred during the year 2014 e 2020 which led to the occurrence of water deficit culminating in a reduction in the harvest $\mathrm{t}^{3-5}$.

Therefore, studies like the present, which aim to study the response to abiotic stresses such as drought, and to identify potential tolerance markers, can provide producers with fundamental tools to minimize the effects of environmental limitations. The genetic improvement program of Minas Gerais, the world's largest coffee producer, works by associating field data with data obtained in a greenhouse to select genotypes with higher productivity coupled with physiological phenotyping to obtain high performance genotypes with multiple characteristics of interest. Tolerance to drought in the field is defined based on productivity under water deficit

\footnotetext{
${ }^{1}$ BDTIIFAPEMIG/EPAMIG Sul, Campus Universitário UFLA, Lavras, Minas Gerais, Brazil. ${ }^{2}$ Universidade Federal de Lavras, Campus Universitário, Lavras, Minas Gerais, Brazil. ${ }^{3}$ Empresa de Pesquisa Agropecuária de Minas Gerais, Epamig Sul, Campus da Universidade Federal Lavras - UFLA, Rodovia Lavras/ljaci Km 02, Cx. P. 176, Lavras, Minas Gerais, Brazil. ${ }^{2}$ Embrapa Café, Inova Café, Campus Universitário da Universidade Federal de Lavras, Lavras, Minas Gerais, Brazil. ${ }^{5}$ Empresa de Pesquisa Agropecuária de Minas Gerais, Epamig Oeste, Patrocínio, Minas Gerais,

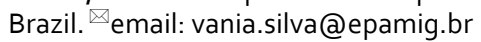


conditions $^{6}$. And with that in order to carry out the physiological analyses, we started from selected genotypes under field conditions, that is, with the desired phenotype, and then carried out a more detailed phenotyping in the greenhouse in order to identify the differential mechanisms that lead to such a tolerance.

Both, C. arabica and C. canephora genotypes display variability to drought tolerance. In general, C. canephora tolerates prolonged periods of drought than C. arabica ${ }^{7}$. Considering that introgressed arabica progenies with C. canephora may have a potential drought tolerance phenotype, in this work, the focus was the study of progenies derived from crossing Icatu Vermelho IAC 3851-2 and Catimor UFV 1602-215. The Icatu germplasm was obtained from an interspecific hybridization between a tetraploid coffee plant of C. canephora and a plant of the cultivar Bourbon Vermelho of C. arabica. The catimor originated from the crossing of Caturra Vermelho with the Timor hybrid coffee trees, which in turn originated from the natural hybridization between C. arabica and C. canephora. These progenies stood out due to rust resistance, good productivity and cup quality ${ }^{8}$.

In general, coffee trees display a differential reduction on leaf water potential ${ }^{9}$ and stomatal closure in response to abscisic acid biosynthesis and signaling ${ }^{10}$. As a consequence, there is a reduction in the intercellular concentration of $\mathrm{CO}_{2}$ and a greater resistance to the mesophyll, leading to a decreasing photosynthesis rate ${ }^{11}$. In Brazilian coffee-growing regions, such as the south of Minas, periods of drought are commonly associated with high light intensities and temperatures ${ }^{4}$. Drought effects are enhanced when combined with high light intensities that lead to oxidative damage induced by an imbalance in the reaction center ${ }^{12}$. The light energy absorbed by the chloroplasts is dissipated via photosynthetic electron transport, chlorophyll fluorescence and heat dissipation ${ }^{13}$. Therefore, studies related to the chlorophyll $a$ fluorescence-characteristics curves performed in response to photosynthetic-photon flux may indicate the response pattern of photosynthesis and PSII performance of progenies under water deficit ${ }^{12,14-16}$. In addition, these curves can not only access the photosynthetic capacity of the plant, but the potential tolerance under a large scale of radiation intensity ${ }^{17}$. Thus, the exploration of the physiological parameters (leaf-water potential and photosynthetic rates) under drought has helped us to identify progenies tolerant to water deficit.

At the molecular level, previous reports have identified candidate genes in different tissues (leaves, roots, plagiotropic buds) of drought-tolerant (DT) and drought-susceptible (DS) plants of C. canephora ${ }^{18-22}$ and $C$. arabica ${ }^{19,23-25}$ displaying differential expression profiles under drought stress. These CGs were separated in classes: (i) Genes related to ABA synthase and signaling pathway such as CaNCED, CaPYL8a, CaPYL8b, CaPYR1, CaSNRK2.8 and CaSNRK2.10 and CaAHG3 encoding a 9-cis-epoxycarotenoid dioxygenase, ABA receptors and proteins phosphatase, respectively. (ii) genes encoding for transcription factors ABA-independent and -dependent such as CaERF017, CaEDR2 e CaMYB (iii) genes coding for different ascorbate peroxidase isoforms (CaAPX1, $C a A P X 5$ e CaAPX6) which ROS removing enzyme catalyzes the conversion of $\mathrm{H}_{2} \mathrm{O}_{2}$ to $\mathrm{H}_{2} \mathrm{O}$; (iv) genes encoding for a galactinol synthase $\mathrm{CaGolS}$, that catalyzes the key step in Raffinose Family of Oligosaccharides biosynthesis; dehydrin $(C c D H 1)$, and $C a S D D 1$ encoding a subtilisin-like serine protease involved stomatal density and distribution.

Expression analyses and characterization of these candidate genes associated with drought tolerance may lead to the identification of marker polymorphisms with a great potential to assist in the identification and early selection of drought-tolerance coffee genotypes. This, certainly, can have an impact on coffee breeding programs, due to time savings and optimization of resources for the development of drought tolerant cultivars. Currently, the rainfed cultivation system is dominant in small-farmers coffee production and, therefore, the selection and characterization of drought tolerant progenies may lead to new cultivars which could guarantee lower risks and higher income for these coffee farmers. The development of drought-tolerant coffee cultivars may also lead to a better management of natural resources (water) allowing coffee to continue to be produced without irrigation or even reduce its consumption under irrigated systems. It should be emphasized that the progenies studied on this work, also have a rust resistance phenotype, which reduces the production costs and the risks to the environment and rural workers, as less pesticides would be required.

The aim of this study was to identify the correlation between photochemical efficiency and candidate genes expression to elucidate the drought tolerance mechanisms in coffee progenies (Icatu Vermelho IAC 3851-2 $\times$ Catimor UFV 1602-215) previously identified as tolerant in field conditions.

\section{Results}

For this study, three progenies potentially drought tolerant (progenies 5, 12 and 2) and one sensitive (progeny 15) were previously selected in the field, where the average productivity of the most productive progenies (progenies 5,12 and 2) was 70.00 bag ha $^{-1}$ and the vigor score was 10 . The progeny 15 , on the other hand, showed productivity of $34.00 \mathrm{bag} \mathrm{ha}^{-1}$ and the vigor score was 5 .

Leaf $\Psi$ pd with values below-1.0 MPa confirmed the unstressed condition of irrigated plants (Table 1). In this condition, no differences were observed between the progenies in relation to the values of net $\mathrm{CO}_{2}$ assimilation rates (A), stomatal conductance (gs), transpiration (E), vapor pressure deficit (VPD) and leaf temperature (Tleaf), quantum yield of PSII electron transport (ФPSII), ETR photochemical quenching, non-photochemical quenching ( $\mathrm{qN})$ and the NPQ. For variables $\mathrm{A}$, gs and $\mathrm{E}$ there was an increase in their values in the second evaluation followed by a slight decrease in the last, while for the variables VPD and Tleaf, highest values were observed at 35 days after irrigation withdraw. The progeny 15 presented lower leaf water potential compared to the other progenies, reaching values below $-5.0 \mathrm{MPa}$ at 28 and 35 days after irrigation withdraw. It is worth to mention that at 35 days, progeny 12 reached the water potential of $-3.35 \mathrm{MPa}$, while progeny 2 and 5 maintained higher values of water potential, being 1.30 and $1.63 \mathrm{MPa}$, respectively (Table 1). The values of net $\mathrm{CO}_{2}$ assimilation rates (A), stomatal conductance (gs), and transpiration (E) were lower under water deficit conditions than irrigated controls for all progenies at 28 and 35 days. For progeny 15, the values of A, gs and E were $82 \%, 93 \%$ and $90 \%$ 


\begin{tabular}{|c|c|c|c|c|c|c|}
\hline \multirow[b]{2}{*}{ Progeny } & \multicolumn{2}{|l|}{0 days } & \multicolumn{2}{|l|}{28 days } & \multicolumn{2}{|l|}{35 days } \\
\hline & I & NI & I & NI & I & NI \\
\hline \multicolumn{7}{|c|}{$\Psi$ pd (MPa) } \\
\hline 2 & $-0.73 \pm 0.07 \mathrm{aA}$ & $-0.30 \pm 0.03 \mathrm{aA}$ & $-0.47 \pm 0.05 \mathrm{aA}$ & $-0.78 \pm 0.12 \mathrm{aA}$ & $-0.35 \pm 0.03 \mathrm{aA}$ & $-1.30 \pm 0.25 \mathrm{aB}^{\star}$ \\
\hline 5 & $-0.32 \pm 0.04 \mathrm{aA}$ & $-0.50 \pm 0.02 \mathrm{aA}$ & $-0.37 \pm 0.04 \mathrm{aA}$ & $-1.17 \pm 0.04 \mathrm{a} \mathrm{B}^{\star}$ & $-0.38 \pm 0.04 \mathrm{aA}$ & $-1.63 \pm 0.22 \mathrm{aB}^{\star}$ \\
\hline 12 & $-0.62 \pm 0.03 \mathrm{aA}$ & $-0.53 \pm 0.04 \mathrm{aA}$ & $-0.70 \pm 0.12 \mathrm{aA}$ & $-1.02 \pm 0.13 \mathrm{aB}^{\star}$ & $-0.36 \pm 0.05 \mathrm{aA}$ & $-3.35 \pm 0.58 b C^{\star}$ \\
\hline 15 & $-0.73 \pm 0.03 \mathrm{aA}$ & $-0.50 \pm 0.04 \mathrm{aA}$ & $-0.40 \pm 0.04 \mathrm{aA}$ & $-5.97 \pm 0.05 b^{\star}$ & $-0.36 \pm 0.04 \mathrm{aA}$ & $-5.88 \pm 0.10 \mathrm{cB}^{\star}$ \\
\hline \multicolumn{7}{|c|}{$\mathrm{A}\left(\mu \mathrm{mol} \mathrm{CO} \mathrm{CO}^{2} \mathrm{~m}^{-2} \mathrm{~s}^{-1}\right)$} \\
\hline 2 & $6.315 \pm 1.701 \mathrm{aB}$ & $3.945 \pm 0.519 \mathrm{aA}$ & $11.188 \pm 1.412 \mathrm{aA}$ & $5.457 \pm 0.927 \mathrm{aA}^{*}$ & $8.490 \pm 0.360 \mathrm{aAB}$ & $3.793 \pm 0.326 \mathrm{aA}^{*}$ \\
\hline 5 & $7.084 \pm 1.683 \mathrm{aA}$ & $4.633 \pm 0.951 \mathrm{aA}$ & $10.210 \pm 2.183 \mathrm{aA}$ & $3.759 \pm 0.154 \mathrm{abA}^{\star}$ & $8.095 \pm 1.835 \mathrm{aA}$ & $2.463 \pm 0.171 \mathrm{abA}^{*}$ \\
\hline 12 & $5.048 \pm 0.215 \mathrm{aB}$ & $4.243 \pm 1.138 \mathrm{aA}$ & $9.642 \pm 0.992 \mathrm{aA}$ & $4.583 \pm 0.886 \mathrm{abA}^{*}$ & $8.314 \pm 1.727 \mathrm{aAB}$ & $2.113 \pm 0.346 \mathrm{abA}^{*}$ \\
\hline 15 & $4.299 \pm 0.546 \mathrm{aB}$ & $5.249 \pm 1.273 \mathrm{aA}$ & $10.626 \pm 1.416 \mathrm{aA}$ & $2.886 \pm 0.193 \mathrm{bA}^{*}$ & $8.049 \pm 0.638 \mathrm{aAB}$ & $1.401 \pm 0.358 \mathrm{bA}^{*}$ \\
\hline \multicolumn{7}{|c|}{ gs $\left(\mathrm{mol} \mathrm{H}_{2} \mathrm{O} \mathrm{m}^{-2} \mathrm{~s}^{-1}\right)$} \\
\hline 2 & $0.097 \pm 0.046 \mathrm{aB}$ & $0.040 \pm 0.002 \mathrm{aA}$ & $0.179 \pm 0.044 \mathrm{aA}$ & $0.043 \pm 0.005 \mathrm{aA}^{*}$ & $0.071 \pm 0.003 \mathrm{aB}$ & $0.020 \pm 0.003 \mathrm{aA}^{*}$ \\
\hline 5 & $0.080 \pm 0.011 \mathrm{aA}$ & $0.042 \pm 0.012 \mathrm{aA}$ & $0.140 \pm 0.037 \mathrm{aA}$ & $0.033 \pm 0.005 \mathrm{abA}^{\star}$ & $0.079 \pm 0.029 \mathrm{aA}$ & $0.013 \pm 0.003 \mathrm{abA}^{*}$ \\
\hline 12 & $0.067 \pm 0.013 \mathrm{aA}$ & $0.050 \pm 0.015 \mathrm{aA}$ & $0.135 \pm 0.030 \mathrm{aA}$ & $0.042 \pm 0.11 \mathrm{abA}^{\star}$ & $0.092 \pm 0.025 \mathrm{aB}$ & $0.008 \pm 0.001 \mathrm{abA}^{*}$ \\
\hline 15 & $0.047 \pm 0.012 \mathrm{aB}$ & $0.069 \pm 0.019 \mathrm{aA}$ & $0.164 \pm 0.043 \mathrm{aA}$ & $0.028 \pm 0.001 \mathrm{bA}^{*}$ & $0.072 \pm 0.011 \mathrm{aB}$ & $0.005 \pm 0.001 \mathrm{bB}^{*}$ \\
\hline \multicolumn{7}{|c|}{$\mathrm{E}\left(\boldsymbol{\mu \mathrm { mol } \mathrm { H }} \mathrm{O}_{2} \mathrm{~m}^{-2} \mathrm{~s}^{-1}\right)$} \\
\hline 2 & $1.093 \pm 0.322 \mathrm{aB}$ & $0.684 \pm 0.099 \mathrm{aA}$ & $2.753 \pm 0.448 \mathrm{aA}$ & $0.886 \pm 0.124 \mathrm{aA}^{*}$ & $1.663 \pm 0.096 \mathrm{aB}$ & $0.627 \pm 0.126 \mathrm{aA}^{*}$ \\
\hline 5 & $1.224 \pm 0.232 \mathrm{aB}$ & $0.638 \pm 0.117 \mathrm{aA}$ & $2.376 \pm 0.622 \mathrm{aA}$ & $0.678 \pm 0.125 \mathrm{a} \mathrm{A}^{\star}$ & $1.597 \pm 0.558 \mathrm{aAB}$ & $0.358 \pm 0.086 \mathrm{abA}^{*}$ \\
\hline 12 & $0.981 \pm 0.238$ a B & $0.755 \pm 0.166 \mathrm{aA}$ & $2.234 \pm 0.387 \mathrm{aA}$ & $0.857 \pm 0.201 \mathrm{aA}^{*}$ & $1.807 \pm 0.400 \mathrm{aAB}$ & $0.186 \pm 0.015 \mathrm{abA}^{*}$ \\
\hline 15 & $0.639 \pm 0.079 \mathrm{aC}$ & $1.025 \pm 0.276 \mathrm{aA}$ & $2.449 \pm 0.518 \mathrm{aA}$ & $0.615 \pm 0.062 \mathrm{aA}^{*}$ & $1.585 \pm 0.160 \mathrm{aB}$ & $0.150 \pm 0.014 \mathrm{bA}^{*}$ \\
\hline \multicolumn{7}{|c|}{ VPD (kPa) } \\
\hline 2 & $1.348 \pm 0.201 \mathrm{aB}$ & $1.489 \pm 0.149 \mathrm{aA}$ & $1.469 \pm 0.113 \mathrm{aB}$ & $1.806 \pm 0.089 \mathrm{aAB}$ & $2.103 \pm 0.085 \mathrm{aA}$ & $2.236 \pm 0.376 \mathrm{aA}$ \\
\hline 5 & $1.316 \pm 0.103 \mathrm{aA}$ & $1.597 \pm 0.209 \mathrm{aB}$ & $1.522 \pm 0.031 \mathrm{aA}$ & $1.798 \pm 0.080 \mathrm{aB}$ & $1.815 \pm 0.118 \mathrm{aA}$ & $2.394 \pm 0.308 \mathrm{aA}$ \\
\hline 12 & $1.339 \pm 0.188 \mathrm{aB}$ & $1.457 \pm 0.148 \mathrm{aB}$ & $1.534 \pm 0.102 \mathrm{aB}$ & $1.846 \pm 0.134 \mathrm{aAB}$ & $2.004 \pm 0.200 \mathrm{aA}$ & $2.317 \pm 0.376 \mathrm{aA}$ \\
\hline 15 & $1.390 \pm 0.191 \mathrm{aB}$ & $1.474 \pm 0.187 \mathrm{aB}$ & $1.463 \pm 0.126 \mathrm{aB}$ & $1.906 \pm 0.130 \mathrm{aAB}$ & $2.041 \pm 0.155 \mathrm{aA}$ & $2.263 \pm 0.367 \mathrm{aA}$ \\
\hline \multicolumn{7}{|c|}{ T leaf $\left({ }^{\circ} \mathrm{C}\right)$} \\
\hline 2 & $25.2 \pm 0.959 \mathrm{aC}$ & $25.8 \pm 1.150 \mathrm{aC}$ & $29.4 \pm 0.347 \mathrm{aB}$ & $29.9 \pm 0.592 \mathrm{aB}$ & $31.9 \pm 0.311 \mathrm{aA}$ & $31.8 \pm 1.072 \mathrm{aA}$ \\
\hline 5 & $25.0 \pm 0.753 \mathrm{aC}$ & $26.1 \pm 1.148 \mathrm{aC}$ & $29.3 \pm 0.264 \mathrm{aB}$ & $29.9 \pm 0.569 \mathrm{aB}$ & $31.2 \pm 0.419 \mathrm{aA}$ & $32.4 \pm 0.795 \mathrm{aA}$ \\
\hline 12 & $24.9 \pm 1.079 \mathrm{aC}$ & $25.7 \pm 1.120 \mathrm{aB}$ & $29.4 \pm 0.362 \mathrm{aB}$ & $30.0 \pm 0.668 \mathrm{aB}$ & $31.9 \pm 0.600 \mathrm{aA}$ & $32.2 \pm 0.894 \mathrm{aA}$ \\
\hline 15 & $25.1 \pm 0.990 \mathrm{aC}$ & $25.7 \pm 1.137 \mathrm{aC}$ & $29.3 \pm 0.347 \mathrm{aB}$ & $30.3 \pm 0.754 \mathrm{aB}$ & $31.9 \pm 0.510 \mathrm{aA}$ & $32.0 \pm 1.041 \mathrm{aA}$ \\
\hline
\end{tabular}

Table 1. Pre-dawn water potential ( $\Psi$ pd), photosynthetic rate (A), stomatal conductance (gs), transpiration (E), vapor pressure deficit (VPD) and leaf temperature (Tleaf) of 4 irrigated (I) and non-irrigated (NI) progenies at 0,28 and 25 days of evaluation. Means followed by the same lowercase letter in the column and averages followed by the same capital letter in the row in each irrigation condition do not differ statistically from each other at the $5 \%$ probability level by the Duncan test. Means followed by asterisks in the line, for the same time and even progeny, are statistically different at the $5 \%$ probability level by the Duncan test.

lower than the irrigated control at 35 days. When comparing the progenies, there were statistical differences using the Duncan test, highlighting progeny 15 with lower values, especially in relation to progeny 2.

In relation to the parameters $\Delta \mathrm{F}$ and $\Delta \mathrm{Fm}^{\prime}$, positive values were found indicating an increase of $\mathrm{F}$ and $\mathrm{Fm}^{\prime}$ under water deficit (Fig. 1A,B). From the flux density of photosynthesizing photons of $600 \mu \mathrm{mol} \mathrm{m}^{-2} \mathrm{~s}^{-2}$, progeny 2 presented higher $\Delta \mathrm{F}$ while the lowest value was found in progeny 15 . As for $\Delta \mathrm{Fm}^{\prime}$, the progeny 12 presented the highest value when submitted to 162 to $230 \mu \mathrm{mol} \mathrm{m}{ }^{-2} \mathrm{~s}^{-2}$, as compared to the other progenies.

Considering the $\triangle \mathrm{ETR}$, the curves presented negative values, which shows that under water deficit, the ETR of the progenies were lower than when irrigated (Fig. 1C). We should draw attention to progeny 15, which presented a more negative $\triangle \mathrm{ETR}$, and the progeny 12 with $\triangle \mathrm{ETR}$ values close to zero. Of these, progeny 15 presented a more expressive reduction of ETR and progeny 12, a small magnitude of reduction. For progenies 5 and 2, the reduction was intermediate.

As for $\Delta \phi P S I I$, corresponding to the variation of the effective quantum yield, progeny 12 presented a variation close to zero, indicating that the deficit did not reduce the $\phi P S I I$ values, as compared to the irrigated one (Fig. 1D). In the other progenies, the values of the curves were negative and, therefore, the effective quantum yield under water deficit was lower in these progenies. With the increase in the density of photosynthetic photon flux, the differences between the progenies were less pronounced, with no differences occurring at $1100 \mu \mathrm{mol} \mathrm{m}^{-2} \mathrm{~s}^{-2}$.

In general, with increasing photosynthesizing photon flow density, progenies 5 and 12 presented positive values of $\triangle \mathrm{qN}$ and $\triangle \mathrm{NPQ}$, indicating higher $\mathrm{qN}$ and $\mathrm{NPQ}$, when submitted to water deficit (Fig. 1e,f). In contrast, progenies 15 and 2 presented negative values of $\Delta \mathrm{qN}$ and $\triangle \mathrm{NPQ}$, therefore with reduction of these parameters under water deficit. The values of $\Delta \mathrm{qP}$ were negative indicating a reduction of qP under deficit, but the progeny 
A

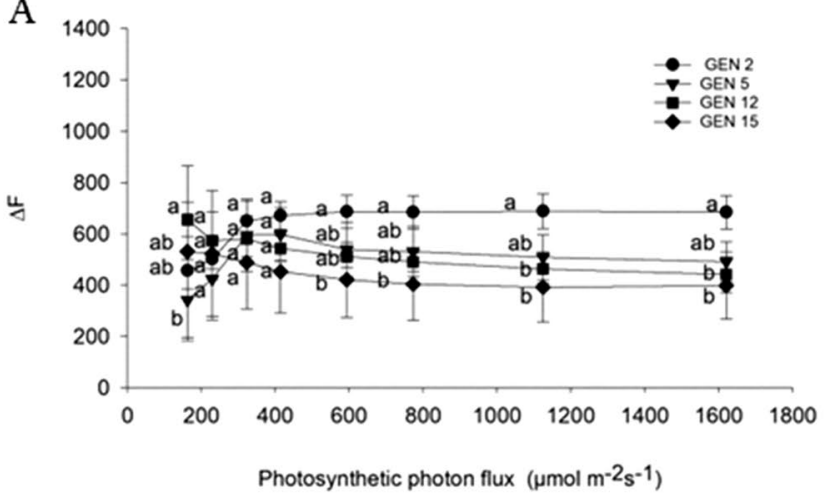

$\mathrm{C}$

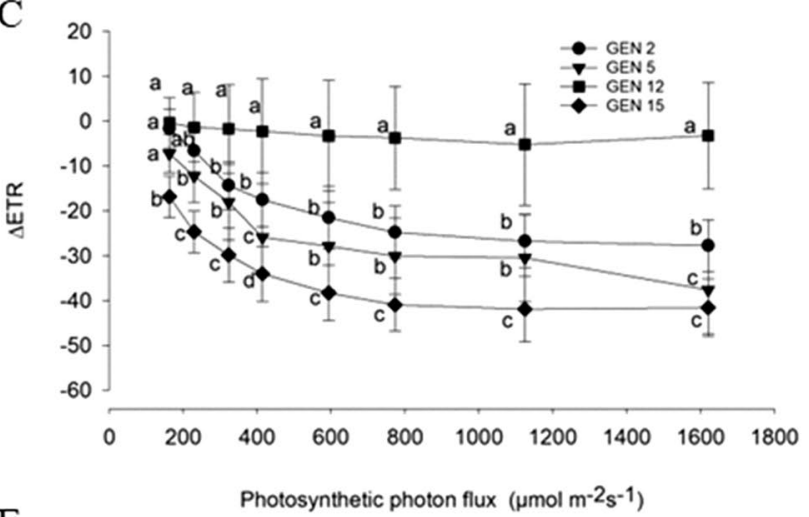

$\mathrm{E}$



B
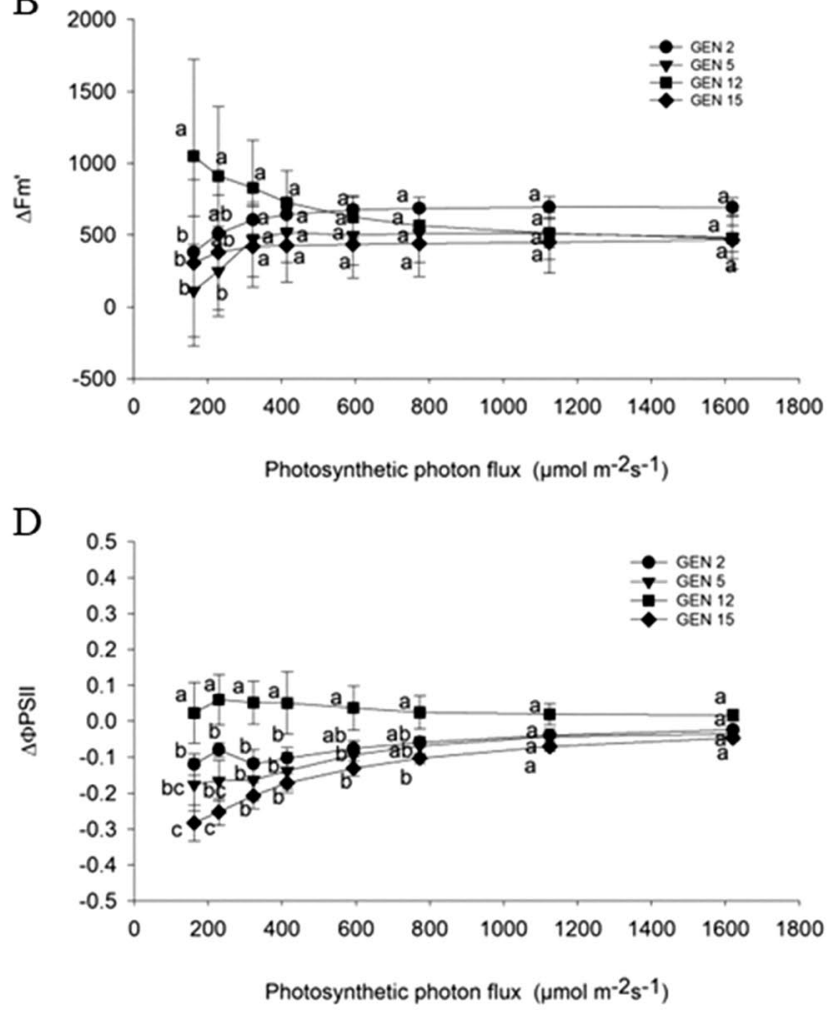

$\mathrm{F}$

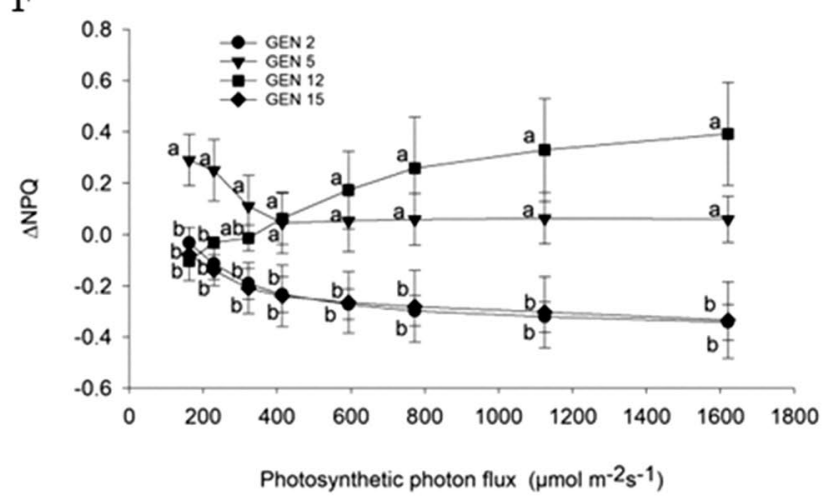

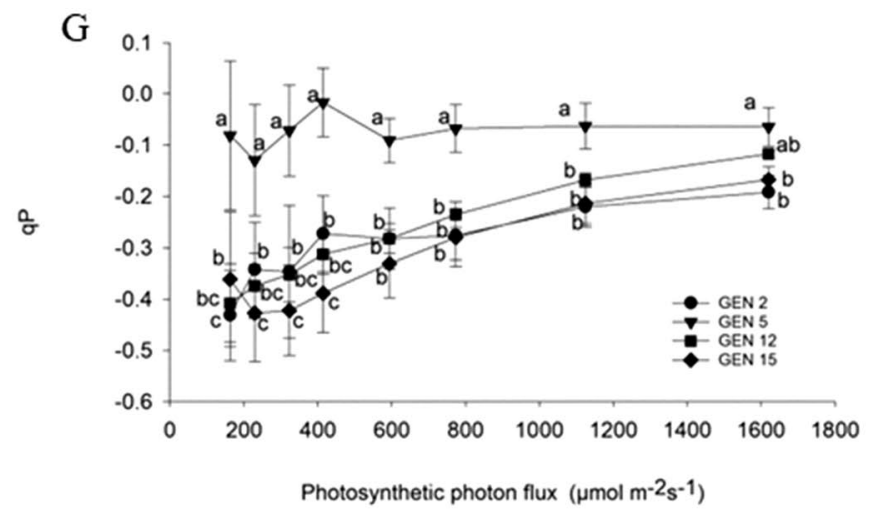

Figure 1. Response curve of the minimum estimated fluorescence of leaves adapted to light (F) (A), of the maximal fluorescence $\left(\mathrm{Fm}^{\prime}\right)(\mathbf{B})$, the relative rate of electron transport (ETR) $(\mathbf{C})$, effective photochemical efficiency of PSII ( FFSII) (D), non-photochemical quenching (qN) (E), the non-photochemical extinction coefficient (NPQ) (F), photochemical quenching (qP) (G) to the increase of the photosynthetic photon flux density (DFFF) in arabica coffee progenies at 35 days of evaluation. 

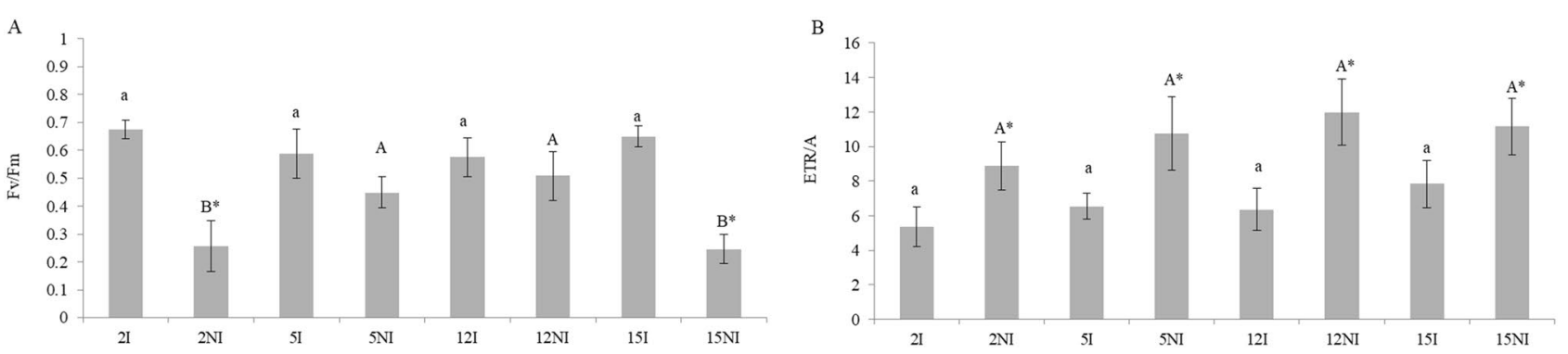

Figure 2. Maximum photochemical efficiency of PSII (Fv/Fm ratio) (A) and electron transport-to-net photosynthesis rate ratio (ETR/A) (B) of 4 irrigated (I) and non-irrigated (NI) progenies at 35 days of evaluation. Ranked results were analyzed using the non-parametric Kruskal-Wallis test followed by a pairwise comparison with the Mann-Whitney test. Significance level were established as p-values $<0.05$, for both tests. Means followed by the same lowercase letter and averages followed by the same capital letter in each irrigation condition do not differ statistically from each other. Means followed by asterisks for even progeny are statistically different.

5, which presented higher values of delta, was observed, indicating that the $\mathrm{qP}$ was less affected in this progeny as compared to the others (Fig. 1g).

Regarding the maximum photochemical efficiency of PSII (evaluated by the Fv/Fm ratio), similar values were observed under irrigated and non-irrigated conditions for progenies 5 and 12 (Fig. 2A). However, the Fv/Fm ratio was lower in the non-irrigated condition compared to the irrigated condition in progenies 15 and 2, with lower values in relation to progenies 5 and 12. In the drought-stressed progenies, the ETR/A ratio enhanced remarkably. However, there were no significant differences between them (Fig. 2B).

In order to verify the correlation between physiological characteristics and gene expression, a statistical analysis was performed, using PCA, at 35 days, when plants effectively reached a water stress (Fig. 3 ). The analyses considered the two PCs corresponding to the two eigenvalues with the highest values, which explained more than $65 \%$ of the variance. Figure $3 \mathrm{~A}$ shows a greater variance explained by the $\mathrm{PC} 1$ for positively associated variances with CaMYB1, CaAPX1, CaGolS3, CaERF017, CaDHN1, CaNCED, CaAPX5 and CaEDR2 and negatively with the physiological characteristics. The PC1 was able to differentiate irrigation regimes, with higher values of gene expression for non-irrigated treatments. On the other hand, in PC2 the variables of greatest contribution were CaMYB1, CaAPX1, CaGols3, CaERF017, CaDHN1, CaNCED, CaAPX5, CaEDR2 and CaPYL8a, together with the fluorescence variables. In this case, progenies 12 and 5 under water deficit conditions were discriminated together with the progenies under irrigated conditions (Fig. 3B). According to the PCA, gene expression analyses will be focused and detailed for the genes that contributed to the formation of PC2, since they were decisive in distinguishing progenies 5 and 12 that showed the greatest photochemical efficiency.

A first univariate analysis for the expression data of candidate genes, all the treatments (time and condition) were grouped by progeny and analyzed statistically. The only significant difference among the expression patterns of the different progenies was found for the CaMYB1 (Fig. 4) In this case, the pattern of relative expression, among all treatments, displayed by the progenies 5 and 12, was statistically different from progenies 2 and 15 (Fig. 4).

The second analysis was performed only with the gene-expression data of the 35 days condition as it was done for the PCA analysis. The obtained results with the 35 day's data analysis among the treatments and progenies showed that statistical differences were observed for the expression data of all genes studied. The results of the analyses of the expression profiles of some transcription factors such as CaERF017, CaMYB1 and CaEDR2 are presented on Figs. 5A-C. For CaERF017 an expressive expression was found at 35 days, with higher values found under non-irrigated progenies 2, 5 and 12 and lower values under both, irrigated and non-irrigated progeny 15 (Fig. 5A). For the CaMYB1 gene- expression levels, progenies 5 and 12 presented the highest expression levels under the non-irrigated condition (Fig. 5B). However, as shown on Fig. 3, high levels of CaMYB1 expression were also observed for progenies 5 and 12, at the time point of 28 days. For the CaEDR2 gene, at 35 days, progenies 2 and 5 presented higher expression levels under both conditions, as compared to the other progenies, with significant higher values under the non-irrigated condition as compared to the irrigated (Fig. 5C).

For CaAPX1, expression was up-regulated in progenies 2, 5 and 12 under the non-irrigated condition (Fig. 5D). Furthermore, for CaAPX5 transcript levels, higher expression values were found for non-irrigated progenies 5 and 12 (Fig. 5E). Higher values of relative expression of CaGolS3 were observed in progeny 5 followed by 12, both under the non-irrigated condition, as compared to the other treatments studied (Fig. 5F).

Results of the CaDHN1, shows that the highest value of relative expression was observed for progeny 5 in the non-irrigated condition, whereas for progeny 12 there was no differential expression between irrigated and non-irrigated condition (Fig. 5G). The highest value of relative expression for the CaNCED gene was presented by progeny 5 non-irrigated at 35 days (Fig. $4 \mathrm{H}$ ). The CaPYL8a gene displayed the higher values for progenies 5 and 12 for the non-irrigated condition as compared to the other treatments (Fig. 5I).

Noteworthy that for all genes tested, as shown on Fig. 5A-I, progeny 15 displayed the lowest levels of gene expression. 
A
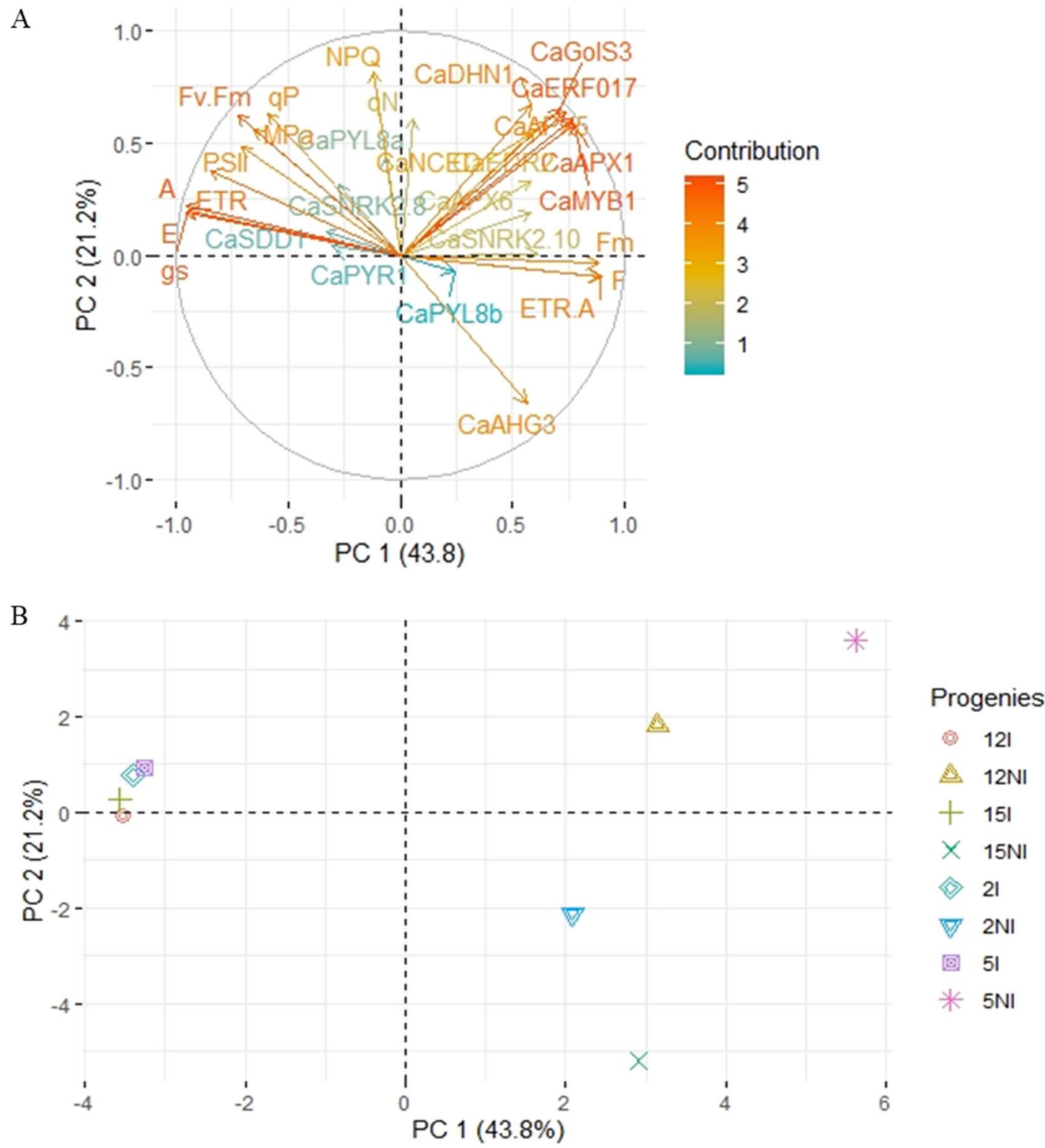

Figure 3. The first two axes of a PCA of all 4 irrigated (I) and non-irrigated (NI) progenies. The size of the vectors (arrows) represents the correlation between variable and PC. The plots show the contribution of the physiological characteristics and several gene expression profile (A) and segregation scores of each progeny under irrigated and non-irrigated conditions (B) for the first two principal components.

\section{Discussion}

In Brazil, the damaging effects of water deficit are enhanced by the high irradiances usually observed in coffeegrowing regions ${ }^{4}$. The coffee tree has a decreased stomatal conductance (gs) under water stress, which leads to a huge oxidative pressure ${ }^{26,27}$. Therefore, progenies which can undertake adjustments in photochemical and molecular processes might better endure drought stress conditions. In this study, we sought to understand about the strategies these different progenies use in order to avoid photochemical damaging.

The results presented here indicated that coffee progenies 2, 5 and 12 that presented high productivity under field conditions in a year of severe water deficit, considered potentially tolerant, showed a different pattern of photochemical and molecular responses to the drought conditions. Progeny 5 showed capacity to maintain water potential, which contributed to lower $\mathrm{qP}$ variation and gas exchange between irrigated and deficit conditions, proving the drought tolerance condition observed in the field. However, $\mathrm{qN}$ and NPQ increases in response to the water stress indicate that this progeny is photochemically responsive to small variations of $\Psi$ pd protecting the photosystem and maintaining qP. As qP represents the portion of absorbed energy that is used in the photochemical step by photosystem II reaction centers ${ }^{17}$, it may also be indicative of the proportion of reaction centers that are open ${ }^{13}$. The highest values of the non-photochemical quenchings $\mathrm{qN}$ and NPQ protect the reaction centers of photosystem II by dissipating excess energy in the form of heat ${ }^{28,29}$. This was also evident from values of Fv/ 
CaMYBI

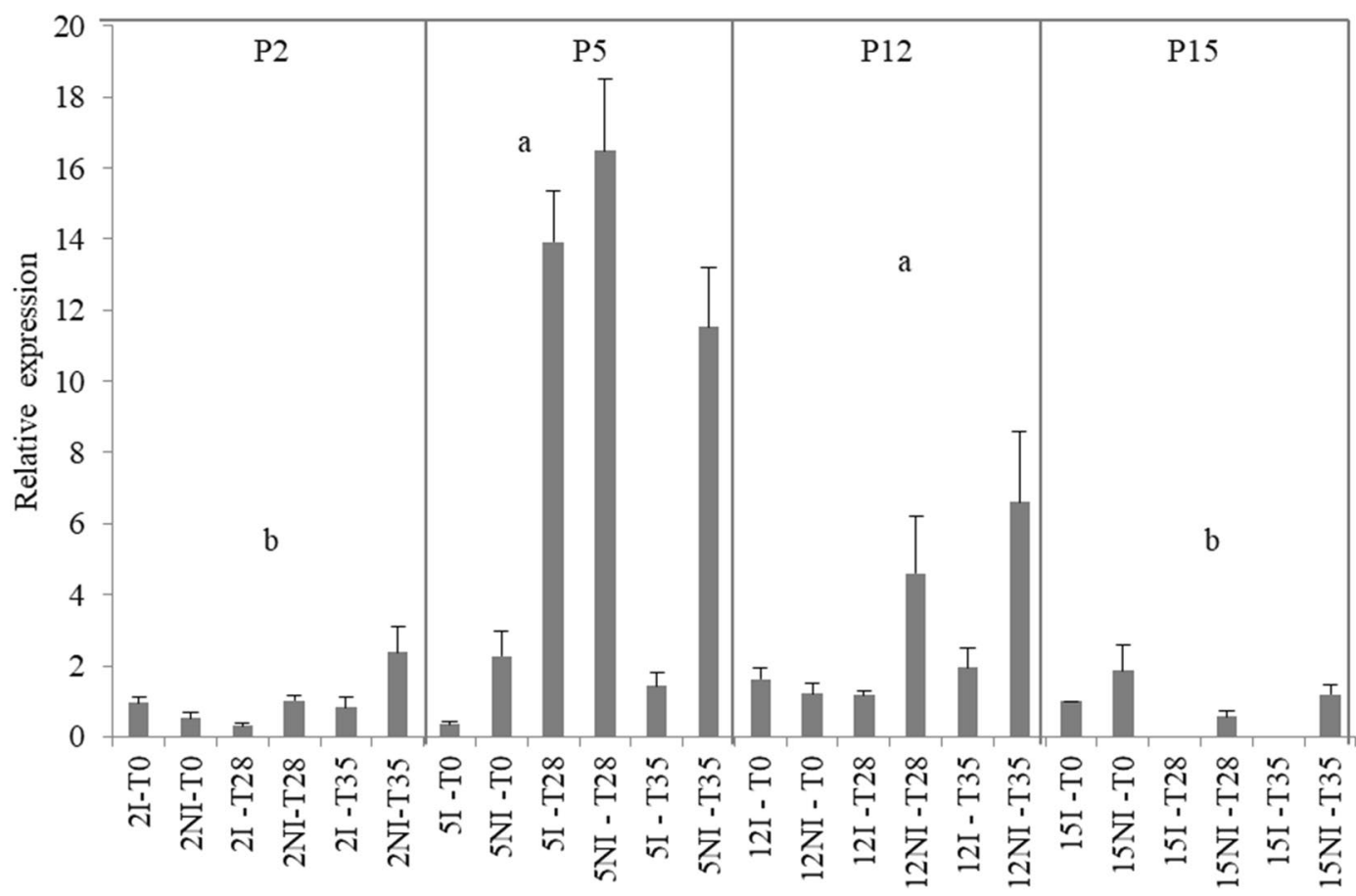

Figure 4. Gene expression profile under irrigated (I) and non-irrigated (NI) conditions. Gene expression of the CaMYB1 gene was analyzed on leaves of coffee progenies 2, 5, 12 and 15. Abundance of transcripts was normalized using $\mathrm{CaUBQ} 10$ gene expression as an endogenous control. The results were expressed using $15 \mathrm{I}$ as the reference sample (Relative Expression $=1$ ). Values of three replicates were presented as means \pm SE (bars). Ranked results of the relative expression data of the progenies were analyzed using the non-parametric KruskalWallis test followed by a pairwise comparison with the Mann-Whitney test. Significance level were established as p-values $<0.05$, for both tests. Progeny patterns of relative expression values followed by the same lowercase letter do not differ statistically from each other.

Fm that remained unchanged in stressed plants, indicating that there was no photoinhibition in this progeny and that light reactions were in a fully active state ${ }^{26}$.

Among the tolerants, progeny 12 presented lower water status maintenance capacity, as verified in the lower values of $\Psi$ pd. It should be noted, however, that the reduction of gas exchange under water deficit showed similar levels to those progenies that maintained the leaf-water potential. In spite of having reduced qP under water deficit, the increase of $\mathrm{qN}$ and NPQ provided maintenance of the photochemical parameters as $\phi P S I I$ and ETR. This shows that this progeny has a certain tolerance of the photosynthetic apparatus to a severe water deficit $(\Psi \mathrm{pd}=-3.35 \mathrm{MPa})$. The stress condition may lead to a slight increase in excitation pressure at the reaction center in the $\mathrm{PSII}^{30}$, as indicated by the decrease in $\mathrm{qP}$, however, not being sufficient to decrease the ETR, which in turn reflects activities of photosystem $\mathrm{II}^{28}$ and the effective photochemical efficiency of PSII ( $\phi$ PSII). The maintenance of Fv/Fm values in this progeny under drought also highlights that there were no PSII inhibitions ${ }^{26}$. Similar results were found by Li et al. ${ }^{28}$ that observed under drought an increase of $\mathrm{qN}$ and decrease of qP in sugar beet leaves, suggesting that excess energy was dissipated as heat, which prevented a photochemical inhibition, due to a decreased degree of reaction-centers opening.

On the other hand, progeny 2 , even with higher $\Psi$ am, proved to be photochemically sensitive, since there was a greater reduction in $\mathrm{qP}, \mathrm{ETR}, \mathrm{qN}, \mathrm{NPQ}$ and Fv/Fm under water deficit. These results indicate that the photosynthetic apparatus may have been damaged by photoinhibition and that it was unable to protect itself against excess energy ${ }^{26,28,31}$.

The progeny 15 exhibited sensitivity to drought, as previously noted under field condition as this progeny had the lowest productivity in the year of occurrence of a severe drought. It presented the lowest capacity of water potential ( $\Psi \mathrm{pd}$ ) maintenance after 28 days of water stress, due to the higher decay rate of this variable among the progenies studied. Progeny 15 showed photochemical sensitivity, with reduction of all fluorescence parameters under water deficit. There is a decrease in $\mathrm{CO}_{2}$ availability for ribulose-1,5-bisphosphate carboxylase/oxygenase (RuBisCO) due to stomatal closure induced by drought. This may causes an excess of energy in the chloroplasts that can lead to an increase in ROS levels, increasing oxidative stress ${ }^{7}$. Thus, drought stress effects on the photosynthetic apparatus of this progeny has typically started with stomatal effects, and ended in metabolic changes caused by severe stress ${ }^{32}$. It is emphasized that the plants were not exposed to different levels of oxidative pressure since there were no differences among the progenies in ETR/A ratio within the same system. However, a high ETR/A ratio was observed in all progenies under drought stress, which are likely associated with an increase in 

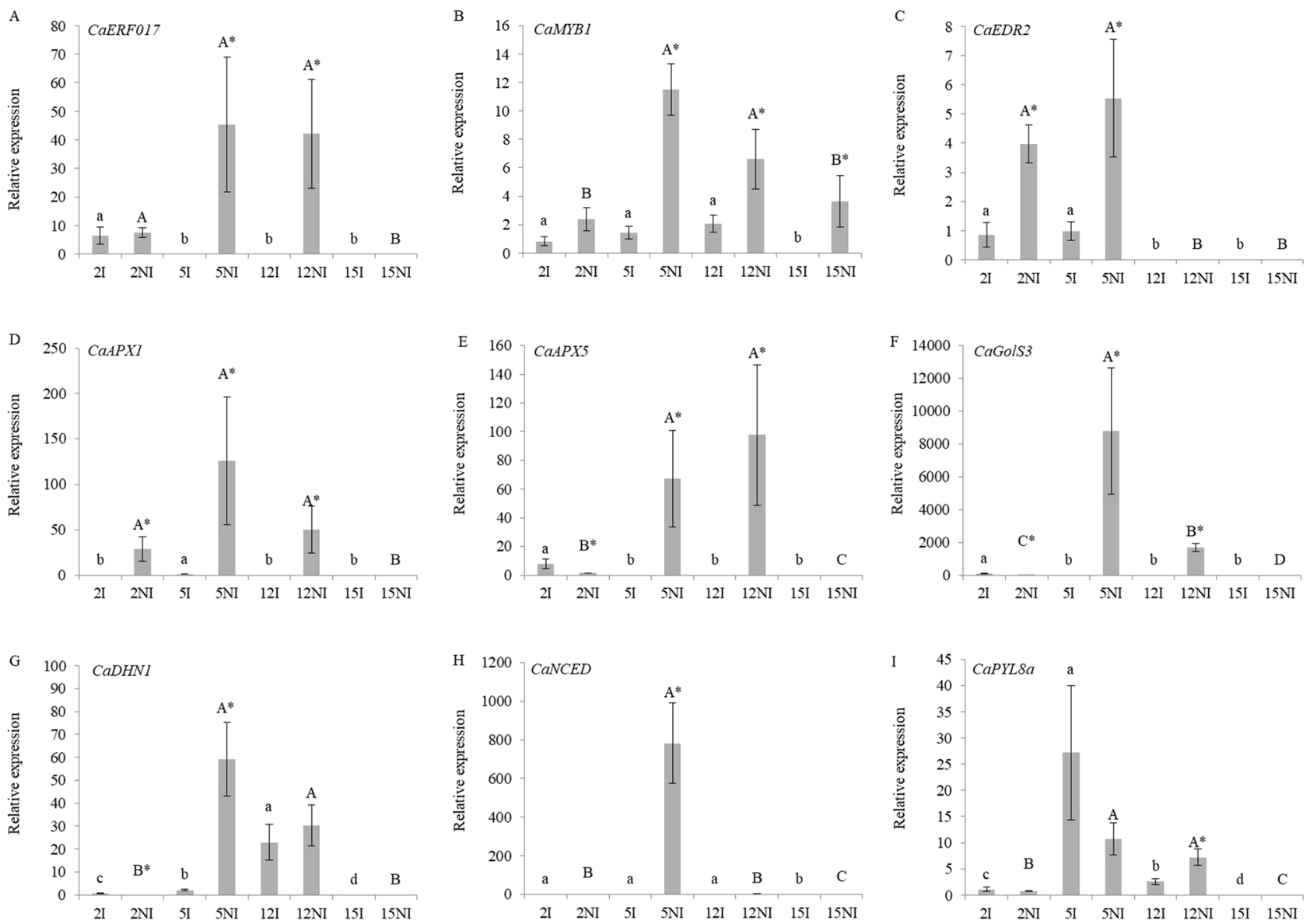

Figure 5. Gene expression profile under irrigated (I) and non-irrigated (NI) conditions. Gene expression was analyzed on leaves of 2, 5, 12 and 15 progenies. (A) CaERF017 gene expression; (B) CaMYB1 gene expression; (C) CaEDR2 gene expression; (D) CaAPX1 gene expression; (E) CaAPX5 gene expression; (F) CaGolS3 gene expression; (G) CaDHN1 gene expression; (H) CaNCED gene expression; (I) CaPYL8a gene expression. Abundance of transcripts was normalized using CaUBQ10 gene expression as an endogenous control. The results were expressed using $15 \mathrm{I}$ as the reference sample (Relative Expression $=1$ ). Values of three replicates were presented as means \pm SE (bars). Ranked results of the relative expression data of the progenies were analyzed using the non-parametric Kruskal-Wallis test followed by a pairwise comparison with the MannWhitney test. Significance level were established as p-values $<0.05$, for both tests. Means followed by the same lowercase letter and averages followed by the same capital letter in each irrigation condition do not differ statistically from each other. Means followed by asterisks for even progeny are statistically different.

reducing power that might lead to oxidative stress ${ }^{27}$. In progeny 15 drought-stressed, a decrease in Fv/Fm was found in relation to well-watered plants, suggesting that effective oxidative damage occurred in these plants. It was also observed that in South African coffee cultivars lower values of Fv/Fm were found in drought-sensitive cultivars $^{26}$. Also, the agronomic vigor analysis showed that progenies that didn't present effective photochemical adjustments had lowest agronomic vigor, marked depletion symptoms and yellowing (leaf scald).

Overall, progenies 5 and 12 showed high photochemical efficiency and energy dissipation capacity, analyzed by the parameters of the chlorophyll a fluorescence curves. Tounekti et al. ${ }^{26}$ studying South African coffee cultivars confirmed that photoprotection is an important factor that affects photosynthetic productivity, and that it varies between the cultivars. Interestingly, the PCA analysis revealed that the expression levels of CaMYB1, CaAPX1, CaGolS3, CaERF017, CaDHN1, CaNCED, CaAPX5, CaEDR2 and CaPYL8a genes clearly displayed the major response to drought stress and discriminated these progenies (5 and 12) under the water-deficit conditions. Accordingly, the gene expression analysis showed that for CaMYB1, CaERF017and CaEDR2, transcript levels coding for these regulatory proteins were higher in the tolerant progenies 5 and 12 as compared to the others. In C. arabica CaERF017 gene was identified as C canephora DREB-like gene ${ }^{25}$. The DREB (Dehydration Responsive Element Binding) gene family corresponds to key transcription factors involved in responses to various abiotic stresses, which regulate the expression of various responsive genes, acting downstream of ABA-dependent and -independent signal transduction pathways ${ }^{33,34}$. The CaERF017 gene was the most expressed DREB-like gene in leaves under low humidity in the drought tolerant clones ${ }^{25}$. The MYB transcription factors have been reported by regulating the biosynthesis of secondary metabolites, regulation of lateral root growth and of the stomatal 
movements ${ }^{35,36}$. The EDR2 gene encodes a protein that acts as a negative regulator of cell death caused by the attack of pathogens and mediated by salicylic acid ${ }^{37}$.

Among ABA-related genes, CaNCED expression highlighted the progeny 5 without irrigation. NCED catalyzes the cleavage of 9-cis-xanthophylls to xanthoxin, which is the key regulation setp of ABA biosynthesis in plants $^{38}$. Accumulation of this hormone can trigger the expression of many stress-responsive genes increase the tolerance of the plant ${ }^{39}$. In C. canephora the tolerant clone 14 showed expression 4 times larger than the other clones in response to drought. NCED gene expressions were strongly induced in response to water stress in tolerant progenies of several common bean progenies ${ }^{40,41}$. The ABA synthesized is perceived by ABA receptors as the PYRABACTIN RESISTANCE1 (PYR1)/PYR1-LIKE (PYL)/REGULATORY COMPONENTS OF ABA RECEPTORS (RCAR) family of proteins ${ }^{42,43}$. Greater expression of CcPYL3 and CcPYL7 was detected in tolerant clones of C. canephora, but with a differential expression between them ${ }^{21}$ as observed in this study for C. arabica with greater expression in progenies 5 and 12 under drought.

The high levels of gene expression encoding isoforms of the antioxidant enzyme ascorbate peroxidase in progenies 5 and 12, mainly under water deficit condition, may be related to the maintenance of the gas exchanges and greater photochemical efficiency in these progenies under non-irrigated condition. The excess excitation energy can lead to the production of reactive oxygen species (ROS) that can oxidize lipids, proteins and nucleic acids in water deficit condition ${ }^{44}$. The peroxidase enzyme ascorbate (APX) plays a key role in the removal of ROS, catalyzing the conversion of $\mathrm{H}_{2} \mathrm{O}_{2}$ to $\mathrm{H}_{2} \mathrm{O}$, using ascorbate with the electron donor ${ }^{45}$. Thus, increased expression of enzymes antioxidants may provide greater protection of photosystem II and other membranes to oxidative stress, contributing to efficiency of the photochemical phase of photosynthesis in these genotypes that showed the highest values of Fv/Fm.

Similarly, the CaGolS3 expression was detected with higher levels in the progenies 5 and 12, corroborating with the literature that shows that in C. arabica the GolS3 isoform is highly expressed under moderate and severe drought conditions ${ }^{46}$. In C. canephora a fourfold higher expression was also observed in the tolerant clone 14 under drought condition ${ }^{18}$. CaGolS3 gene encodes an isoform of the enzyme galactinol synthase that is involved in the first step of oligosaccharide synthesis in the raffinose (RFOs) Family. RFOs are involved both in osmoprotection as in ROS scavenging, thus promoting increased protection the photosynthetic apparatus against oxidative damages caused by various stresses such as drought ${ }^{47}$. On the other hand, the lower levels of expression of these genes in progeny 2 may have contributed to the decrease of all fluorescence values, perhaps because of a less effective protective and antioxidant action.

Noteworthy is also that the CaDHN1 gene expression was found in non-irrigated plants mainly in progenies 5 and 12. Dehydrins are known as a group II of LEA proteins (Late embryogenesis abundant), accumulated in the later stages of development in response to the most diverse environmental stresses, participating significantly in the stabilization of membranes, enzymes and nucleotides ${ }^{48}$. The expression of dehydrins can be strongly induced by abiotic stresses ${ }^{49,50}$, being more expressed in tolerant clones ${ }^{18,22}$.

In our study, the better photochemical efficiency and greater capacity to dissipate unused energy in photosynthesis, was clearly associated with higher gene expression levels coding for regulatory proteins, ABA-synthesis, cellular protectors and isoforms of the antioxidant enzyme ascorbate peroxidase, indicating that these genes can contribute to maintaining the integrity of the photosynthetic apparatus in progenies tolerant to water deficit. On the other hand, progeny 15 showed photochemical sensitivity, as well as the lowest expression levels of almost all genes tested. In addition these results are also in agreement with the lowest productivity of progeny 15, observed under field conditions in a year of a severe drought period.

Progenies with better photochemical efficiency and greater capacity to dissipate unused energy in photosynthesis may present better condition to maintain its function under low leaf water status and to recovery after a period of severe drought, under a large scale of radiation intensity.

\section{Material and methods}

Plant material. The Coffea arabica progenies were selected by the coffee breeding program conducted and coordinated by Agricultural Research Enterprise of Minas Gerais (EPAMIG, Lavras, Minas Gerais, Brazil) with the participation of the Universidade Federal de Lavras (UFLA) and the Universidade Federal de Viçosa (UFV). The four progenies in the F6 generation (2 (H 29-1-8-5-14-2), 5 (H 136-1-19-7-14-4), 12 (H 136-1-19-4-65) and15 (H 30-3-14-1-19-9-12)) were selected in an experiment at the EPAMIG Experimental Field of São Sebastião do Paraiso (CESP, Minas Gerais, Brazil) from 'Icatu (3851-2-UFV 2117) and Catimor UFV 5373' crossing, based on data on productivity and agronomic vigor observed in 2014/2015 crop year (a period with severe water deficits in this region). According to the EPAMIG genetic improvement program database, three more productive genotypes with maximum agronomic vigor (progenies 5, 12 and 2) and one less productive and with lowest agronomic vigor (progeny 15) were selected. Plants were scored according to a ten point arbitrary scale in which score 1 corresponds to plants with the poorest vegetative vigor and marked depletion symptoms. The score 10 indicates plants with excellent vigor, more leafy and with marked vegetative growth of the productive branches ${ }^{51,52}$. Productivity is measured by weighing the fruit immediately after harvest. Then a sample of about $3 \mathrm{~L}$ from each plot is weighed and placed for drying in the sun. After drying, the coffee is weighed, processed and weighed again to calculate productivity in processed bags per hectare (bag ha-1).

The use of coffee progenies in the present study has the appropriate permissions and/or licenses of the EPAMIG coffee breeding program. The use of coffee plants parts complies with international, Brazilian and institutional guidelines.

Experimental procedures. The experiment was carried out in a greenhouse with free exchange of air located in the latitude of $21^{\circ} 14^{\prime} 30^{\prime \prime}$ South and longitude of $45^{\circ} 00^{\prime} 10^{\prime \prime}$ West and altitude of 918,841 m (Main 
Climatological Station of Lavras). The minimum, average and maximum temperatures and relative humidity and photosynthetically active radiation of the greenhouse during the experimental period were $17{ }^{\circ} \mathrm{C}, 26^{\circ} \mathrm{C}$, $35^{\circ} \mathrm{C}, 39 \%, 63 \%, 87 \%$ and $300 \mu \mathrm{mol} \mathrm{m}{ }^{-2} \mathrm{~s}^{-1}$, respectively.

The seedlings were grown in $20 \mathrm{~L}$ polyethylene pots, with a substrate consisting of a mixture of subsoil soil, sand and bovine manure (3: $1: 1, \mathrm{v} / \mathrm{v} / \mathrm{v})$. The fertilization was carried out according to the substrate analysis, following the recommendations of Guimarães et al. ${ }^{53}$. Phytosanitary treatments were carried out preventively to control the main pests and diseases of higher incidence in the region. After being transferred to the pots, the seedlings were kept in a greenhouse, with free exchange of air during a period of eight months.

Until the day before the application of the water treatments all plots were irrigated in order to maintain the substrate of the vase in the field capacity (FC). In order to control the amount of water applied in each vessel, the humidity sensor (ML2X THETA PROBE, Delta-T Devices) was used and calibrated according to soil water moisture, from soil saturation to field capacity. The relative soil moisture at $100 \%$ field capacity was $0.46 \mathrm{~m}^{-3} \mathrm{~m}^{-3}$. After the eight-month period, the plants were separated into two groups. In the first group (i.e., irrigated plants (I), control), plants remained irrigated, maintaining $100 \%$ of the field capacity. The plants from the second group (i.e., drought-stressed plants (NI)) were not watered until the soil water content reached approximately $35 \%$ FC (i.e., $0.16 \mathrm{~m}^{-3} \mathrm{~m}^{-3}$; ca. 28 days). They were then maintained at $35 \% \mathrm{FC}$ for additional 7 days, (i.e., $0.16 \mathrm{~m}^{-3} \mathrm{~m}^{-3}$; ca. 35 days) in all progenies.

Experimental layout. The experiment was set up in a randomized complete block design (RCBD) with split split plot in time. The experiment consisted of 8 treatments, in a $4 \times 2$ factorial scheme, four progenies and two water treatments. The subplots were the different epochs of evaluation $(0,28$ and 35 days after the beginning of the experiment). Four replicates were used and each experimental plot consisted of one plant. In total, we used 32 plants, 8 per progeny (4 irrigated, 4 non-irrigated).

Statistical analyses. Physiological traits were evaluated by analysis of variance using the F test, with the Duncan's New Multiple Range Test (DNMRT) at 5\% probability for to perform the mean differences using the R software ${ }^{54}$ and agricolae package ${ }^{55}$. The physiological traits and gene expression profiles were also analyzed by Principal Component Analysis (PCA), using the R software ${ }^{54}$ and the FactoMineR package ${ }^{56}$.

For the RT-qPCR results, Fv/Fm and ETR/A, ranked results were analyzed using the non-parametric kruskal-Wallis test followed by a pairwise comparison with the Mann-Whitney test. Significance levels were established as p-values $<0.05$, for both tests. The spreadsheet software Excel was used to perform the analyses.

Physiological traits. All samplings and measurements were made using leaves from the third or fourth pair of apex plagiotropic branches.

Leaf samples for pre-dawn water potential ( $\Psi$ pd) measurements were collected between 3 and 5 am. The collected leaves were placed in plastic bags, properly closed and identified according to each treatment. Then the samples were placed in a thermal box with ice, to avoid excessive water loss, and taken to the place where Ipd measurements were made using the Scholander-type pressure chamber (PMS Instruments Plant MoistureModel 1000).

The net photosynthetic rate $\left(\mathrm{A}-\mu \mathrm{mol} \mathrm{CO} \mathrm{Cm}^{-2} \mathrm{~s}^{-1}\right)$, stomatal conductance (gs- $\left.\mathrm{molH}_{2} \mathrm{O} \mathrm{m}^{-2} \mathrm{~s}^{-1}\right)$, transpiration $\left(\mathrm{EmmolH}_{2} \mathrm{O} \mathrm{m}^{-2} \mathrm{~s}^{-1}\right)$, vapor pressure déficit $(\mathrm{VPD}-\mathrm{kPa})$ and leaf temperature (Tleaf- $\left.{ }^{\circ} \mathrm{C}\right)$ were measured between 8:00 and 11:00 am under an artificial source of photosynthetically active radiation (PAR), in a closed chamber fixed in $1500 \mu \mathrm{mol}$ of photons $\mathrm{m}^{-2} \mathrm{~s}^{-1}$ (Blue + Red LED LI-6400-02B, LI-COR, Lincoln, USA) with a infrared gas analyzer (LI-6400XT Portable Photosynthesis System, LICOR, Lincoln, USA). The $\mathrm{CO}_{2}$ assimilation rate in the chamber was measured with the ambient $\mathrm{CO}_{2}$ concentration.

Chlorophyll fluorescence was measured with a pulse amplitude modulation fluorometer (MINI PAM-1999, Heinz Walz GmbH, Effeltrich, Germany). The analyzes were carried out following the methodology described by Schreiber et al. ${ }^{57}$ and Genty et al. ${ }^{58}$ and the terminologies and calculations proposed by Snel and Van Kooten ${ }^{59}$. Leafclips were used for measurements of the minimum (F0) and maximum (Fm) fluorescence yield in darkadapted (30 min) leaf tissues. The minimum fluorescence (F0) was measured using a weak modulated measuring beam (ca. $0.03 \mu \mathrm{mol} \mathrm{m} \mathrm{m}^{-2} \mathrm{~s}^{-1}$ ). Subsequently, the maximal fluorescence $(\mathrm{Fm})$ was measured by applying a saturating actinic light pulse $\left(>6000 \mu \mathrm{mol} \mathrm{m}^{-2} \mathrm{~s}^{-1}\right)$ for $0.8 \mathrm{~s}$. Thus, it was possible to calculate the maximum photochemical efficiency of photosystem II (PSII), Fv/Fm $=(\mathrm{Fm}-\mathrm{Fo}) / \mathrm{Fm}$.

In light-adapted leaf tissues, instant light-response curves were obtained using the light-curve program of the Mini-PAM. The photosynthetic photon flux, ranging from 0 to $1620 \mu \mathrm{mols} \mathrm{m}^{-2} \mathrm{~s}^{-1}$ for a period of $4 \mathrm{~min}$ in eight steps following each other within $30 \mathrm{~s}$. At the end of each light level, a saturating pulse was applied to determine fluorescence parameters. These $\mathrm{Chl}$ fluorescence parameters were used to effective photochemical efficiency of PSII $\left(\Phi F S I I=\Delta \mathrm{F} / \mathrm{Fm}^{\prime}\right)$, the apparent electron transport rate $\left(\mathrm{ETR}=\left(\Delta \mathrm{F} / \mathrm{Fm}^{\prime} \times \mathrm{PPFD} \times 0.5 \times 0.84\right)\right.$, the photochemical quenching $\left(\mathrm{qP}=\left(\mathrm{Fm}^{\prime}-\mathrm{F}\right) /\left(\mathrm{Fm}^{\prime}-\mathrm{F}^{\prime}\right)\right)$ and the non-photochemical quenching $\left[\mathrm{NPQ}=\left(\mathrm{Fm}^{\prime}-\mathrm{Fm}^{\prime}\right) /\right.$ $\left.\left.\mathrm{Fm}^{\prime} ; \mathrm{qN}=\mathrm{Fm}-\mathrm{Fm}^{\prime} / \mathrm{Fv}\right)\right]^{60}$. For ETR calculation, it was assumed that quanta were evenly distributed between PSII and PSI (0.5), and leaf light absorption was considered to be $0.84^{61}$. At 35 days of stress imposition the light curves were presented as delta values $(\Delta)$, i.e., the difference between the values of the progenies under water deficit in relation to the irrigated control. This evaluation also included Fv/Fm and electron transport-to-net photosynthesis rate ratio (ETR/A).

RNA extraction. Samples samples from each replicate stored at $-80^{\circ} \mathrm{C}$ were ground into a powder in liquid nitrogen and the total RNA was extracted following the recommendations of the Plant RNA Purification Reagent (PRPR) manual (Invitrogen). 


\begin{tabular}{|c|c|c|c|}
\hline Gene & Protein name & Sequence $\left(5^{\prime}-3^{\prime}\right)$ & GB numbers \\
\hline CaDHN1 & Dehydrin & $\begin{array}{l}\text { F:CCCCTGGTCTGAGCTCGTT } \\
\text { R:GACGCGGAAGTAGGCGTAATT }\end{array}$ & \\
\hline CaEDR2 & EDR1-like MAPKK kinase & $\begin{array}{l}\text { F:CGGCATAAGAGCGAGTGGAA } \\
\text { R:ATGCAATCGCTGGTGTAGAAAA }\end{array}$ & DV681462 \\
\hline CaMYB1 & MYB-type 2 transcription factor & $\begin{array}{l}\text { F:CCCGGCAATCTTCCAGCTA } \\
\text { R:TCAAGCGTGGCAACTTCACT }\end{array}$ & GT689406 \\
\hline CaNCED & 9-cis-epoxycarotenoid dioxygenase 3 & $\begin{array}{l}\text { F:GCCTGGGAAGAGCCTGAAAC } \\
\text { R:CCCCTCGTCACATTCATTGAA }\end{array}$ & \\
\hline CaERF017 & Dehydration-responsive element-binding & $\begin{array}{l}\text { F:ATTCCGCCTGGAGCTCAAGT } \\
\text { R:GGTGGTCCAGTTGGAGAGTGA }\end{array}$ & \\
\hline CaSDD1 & Subtilisin-like serine protease & $\begin{array}{l}\text { F:GAGCCCCGATTGATCTTCTG } \\
\text { R:ACTCAGCCCCAAAAGGGTTAA }\end{array}$ & \\
\hline CaGols3 & Galactinol synthase & $\begin{array}{l}\text { F:CCCTTTGGTGGTTGCAGTTT } \\
\text { R:AGGCTCGATCTCCCGGACTATA }\end{array}$ & \\
\hline CaAPX1 & Ascorbate peroxidase & $\begin{array}{l}\text { F:GACCTGAACAATGCCCAGAAG } \\
\text { R:CGTAAATGAGCAGCAGGTGATG }\end{array}$ & GT697455 \\
\hline СаAPX6 & Ascorbate peroxidase & $\begin{array}{l}\text { F:AGACCGTGTCTCAAACCGACTAC } \\
\text { R:GTTGATCTGTTGGCCCAAAGA }\end{array}$ & EE193467 \\
\hline CaAPX5 & Ascorbate peroxidase & $\begin{array}{l}\text { F:ATCCAGAGGGCAGGGTACCT } \\
\text { R:ACCAAAGCCGAGAGCAGTGA }\end{array}$ & \\
\hline CaPYL8a & Abscisic acid receptor PYL8 & $\begin{array}{l}\text { F:GGTTTGATCAGCCCCAGAAA } \\
\text { R:CCACTTCCCTAAGGCTTCCAA }\end{array}$ & \\
\hline CaPYL8b & Abscisic acid receptor PYL8 & $\begin{array}{l}\text { F: GCCAGAGGGAAATACCAAGGA } \\
\text { R: CAGCTAGGCGCTCTGAGACA }\end{array}$ & \\
\hline CaPYR1 & Abscisic acid receptor PYR1 & $\begin{array}{l}\text { F:CGGTGACGACTGTCCATGAG } \\
\text { R:TCCGGCACGTCAACGATATA }\end{array}$ & \\
\hline CaAHG3 & Protein phosphatase & $\begin{array}{l}\text { F: ACCGGAGGTGACGATAATCG } \\
\text { R: CCCACAAGCTGTGTCATTGG }\end{array}$ & \\
\hline CaSNRK 2.8 & Serine/threonine-protein kinase SAPK2 & $\begin{array}{l}\text { F: CCGCTTCAAAGAGGTCTTGCT } \\
\text { R: TTCTCCTCCTGCCGCATACT }\end{array}$ & \\
\hline CaSNRK 2.10 & Serine/threonine-protein kinase SAPK2 & $\begin{array}{l}\text { F: TCGATTCAAGGAGGTGGTGTT } \\
\text { R: TTCCCCTCCAGCTGCATACT }\end{array}$ & \\
\hline CaUBQ10 & Ubiquitin & $\begin{array}{l}\text { F: AAGACAGCTTCAACAGAGTACAGCAT } \\
\text { R: GGCAGGACCTTGGCTGACTATA }\end{array}$ & GW488515 \\
\hline
\end{tabular}

Table 2. Candidate genes for drought tolerance, protein name, corresponding primers and GenBank (GB) accession numbers of coffee EST sequences used in the qPCR experiment.

RNA quantification was performed using a NanoDrop 1000 Spectrophotometer (Thermo Scientific, Waltham, MA, USA). RNA integrity was measured by $1 \%$ electrophoresis gel analysis of agarose stained with ethidium bromide. The genomic DNA contaminant was removed from the RNA samples by treatment with RQ1 RNasefree DNase (Promega) according to the manufacturer's instructions.

qPCR real-time assay. For real-time quantitative PCR, the first strand cDNA was synthesized using $1 \mu \mathrm{g}$ of total RNA, the ImProm-II Reverse Transcription System and oligo(dT15) according to the manufacturer's recommendations (Promega, Madison, WI, USA). Real-time quantitative PCR (RT-qPCR) experiments were carried out using the protocol recommended for the use of a 7500 Fast Real-Time PCR System (Applied Biosystems, Foster City, CA, USA) as previously described by Marraccini et al. ${ }^{21}$. Primers (Table 2) were designed using Primer Express software (Applied Biosystems) and were preliminarily tested for their specificity and efficiency against a cDNA mixture from leaves. Data were analysed using 7500 Fast Software v2.0.6 (Applied Biosystems) to determine cycle threshold $(\mathrm{Ct})$ values. The specificity of the PCR products generated for each set of primers was verified by analysing the Tm (dissociation) of amplified products. PCR efficiency $(E)$ was estimated using absolute fluorescence data captured during the exponential phase of amplification of each reaction with the equation $(1+E)=10(-1 / \text { slope })^{62}$. Expression levels were calculated by applying the formula $\left(1+E^{--\Delta \Delta C t}\right.$ where $\Delta C \mathrm{t}_{\text {target }}=C \mathrm{t}_{\text {targetgene }}-C \mathrm{t}_{\text {CaUBQ }}$ and $\Delta \Delta C \mathrm{t}=\Delta C \mathrm{t}_{\text {target }}-\Delta C \mathrm{t}_{\text {reference sample. }}$ Gene expression levels were normalized to the expression level of the $C a U B Q 10^{63}$ reference gene. Genotype 15 irrigated at zero time was used as internal calibrator with relative expression equal to 1 .

Selection of candidate genes. From previous studies, several candidate genes were identified in different tissues (leaves, roots, plagiotropic buds) of drought-tolerant (DT) and drought-susceptible (DS) plants of C. canephora ${ }^{18-22}$ and C. arabica ${ }^{19,23-25}$ displaying differential expression profiles under drought stress. Of these genes, 16 candidate genes (Table 2) were selected to be tested on leaves of the four progenies from the crossing 'Icatu (3851-2-UFV 2117) $\times$ Catimor UFV 5373' under control and drought conditions. These genes corresponded to CaERF017, CaMYB1, CaEDR2, CaGolS3, CaDHN1, CaSDD1, CaAPX1, CaAPX5, CaAPX6, CaNCED, CaPYL8a, CaPYL8b, CaPYR1, CaSNRK2.8, CaSNRK2.10 and CaAHG3. 


\section{Data availability}

All data generated or analysed during this study are included in this published article.

Received: 4 November 2020; Accepted: 15 March 2021

Published online: 01 April 2021

\section{References}

1. International Coffee Organization (ICO) (2019). http://www.ico.org/prices/po-production.pdf. Accessed on 6 Aug 2020.

2. de Freitas Guedes, F. A., Menezes-Silva, P. E., DaMatta, F. M. \& Alves-Ferreira, M. X. Using transcriptomics to assess plant stress memory. Theor. Exp. Plant. Physiol. 31, 47-58 (2019).

3. CONAB- COMPANHIA NACIONAL DE ABASTECIMENTO. Quarto levantamento: dezembro 2014 (2014). http://www.conab. gov.br/OlalaCMS/uploads/arquivos/14_12_22_09_53_55_boletim_dezembro_2014.pdf. Accessed 4 Nov 2019.

4. Martins, E., Aparecido, L. E. O., Santos, L. P. S., Mendonça, J. M. A. \& Souza, P. S. Influência das condições climáticas na produtividade e qualidade do cafeeiro produzido na região do sul de Minas Gerais. Coffee Sci. 10, 499-506 (2015).

5. NASDAQ- Stock Market (2020). https://www.nasdaq.com/articles/brazil-coffee-farmers-see-losses-from-drought-in-2021-crop2020-09-11. Accessed 8 Oct 2020.

6. Cheserek, J. J. \& Gichimu, B. M. Drought and heat tolerance in coffee: A review. Int. Res. J. Agric. Sci. Soil Sci. 2, 498-501 (2012).

7. Damatta, F. M., Avila, R. T., Cardoso, A. A., Martins, S. C. V. \& Ramalho, J. C. Physiological and agronomic performance of the coffee crop in the context of climate change and global warming: A review. J. Agric. Food Chem. 66, 5264-5274 (2018).

8. Botelho, C. E., Mendes, A. N. G., Carvalho, G. R., Bartholo, G. F. \& Carvalho, S. P. Seleção de progênies F4 de cafeeiros obtidas pelo cruzamento de Icatu com Catimor. Rev. Ceres 57, 274-281 (2010).

9. Menezes-Silva, P. E. et al. Wood density, but not leaf hydraulic architecture, is associated with drought tolerance in clones of Coffea canephora. Trees Struct. Funct. 29, 1687-1697 (2015).

10. Silva, V. A. et al. Reciprocal grafting between clones with contrasting drought tolerance suggests a key role of abscisic acid in coffee acclimation to drought stress. Plant Growth Regul. 85, 221-229 (2018).

11. Menezes-Silva, P. E. et al. Photosynthetic and metabolic acclimation to repeated drought events play key roles in drought tolerance in coffee. J. Exp. Bot. 68, 4309-4322 (2017).

12. Banks, J. M. Chlorophyll fluorescence as a tool to identify drought stress in Acer genotypes. Environ. Exp. Bot. 155, 118-127 (2018).

13. Murchie, E. H. \& Lawson, T. Chlorophyll fluorescence analysis: A guide to good practice and understanding some new applications. J. Exp. Bot. 64, 3983-3998 (2013).

14. Falqueto, A. R. et al. Effects of drought stress on chlorophyll a fluorescence in two rubber tree clones. Sci. Hortic. 224, 238-243 (2017).

15. Liang, G. et al. Effects of drought stress on the photosynthetic physiological parameters of Populus $\times$ euramericana "Neva". J. For. Res. 30, 409-416 (2019).

16. Wang, Z. et al. Effects of drought stress on photosynthesis and photosynthetic electron transport chain in young apple tree leaves. Biol. Open 7, 035279 (2018).

17. Henriques, F. S. Leaf chlorophyll fluorescence: Background and fundamentals for plant biologists. Bot. Rev. 75, 249-270 (2009).

18. Costa, T. S. Análises do Perfil Transcriptômico e Proteômico de Raízes de Diferentes Clones de Coffea canéfora em Condições de Déficit Hídrico. PhD dissertation, Universidade Federal de Lavras (2014). http://repositorio.ufla.br/jspui/handle/1/4695. Accessed 11 Sep 2020

19. Cotta, M. G. et al. The first step of aba perception and signal transduction in coffee: Evolutionary and expression of PYR/PYL/ RCARs, PP2Cs and SNRK2s genes in C. canephora under drought. In 26th International Conference on Coffee Science, 2016, Kunming-China. Book of Abstracts (2016).

20. Marraccini, P. et al. RBCS1 expression in coffee: Coffea orthologs, Coffea arabica homeologs, and expression variability between genotypes and under drought stress. BMC Plant Biol. 11, 85 (2011).

21. Marraccini, P. et al. Differentially expressed genes and proteins upon drought acclimation in tolerant and sensitive genotypes of Coffea canephora. J. Exp. Bot. 63, 4191-4212 (2012).

22. Vieira, N. G. et al. Different molecular mechanisms account for drought tolerance in Coffea canephora var. Conilon. Trop. Plant Biol. 6, 181-190 (2013).

23. Freire, L. P., Marraccini, P., Rodrigues, G. C. \& Andrade, A. C. Análise da expressão do gene manose-6-fosfato redutase em cafeeiros submetidos ao déficit hídrico. Coffee Sci. 8, 17-23 (2013).

24. Mofatto, L. S. et al. Identification of candidate genes for drought tolerance in coffee by high-throughput sequencing in the shoot apex of different Coffea arabica cultivars. BMC Plant Biol. https://doi.org/10.1186/s12870-016-0777-5 (2016).

25. Torres, L. F. et al. Expression of DREB-like genes in Coffea canephora and C. arabica subjected to various types of abiotic stress. Trop. Plant. Biol. 12, 98-116 (2019).

26. Tounekti, T., Mahdhi, M., Al-Turki, T. A. \& Khemira, H. Water relations and photo-protection mechanisms during drought stress in four coffee (Coffea arabica) cultivars from southwestern Saudi Arabia. S. Afr. J. Bot. 117, 17-25 (2018).

27. Avila, R. T. et al. Elevated air [CO2] improves photosynthetic performance and alters biomass accumulation and partitioning in drought-stressed coffee plants. Environ. Exp. Bot. 177, 104137 (2020).

28. Li, G. L., Wub, H. X., Suna, Y. Q. \& Zhanga, S. Y. Response of chlorophyll fluorescence parameters to drought stress in sugar beet seedlings. Russ. J. Plant Physl. 60, 337-342 (2013).

29. Ruban, A. V. Nonphotochemical chlorophyll fluorescence quenching: Mechanism and effectiveness in protecting plants from photodamage. Plant Physiol. 170, 1903-1916 (2016).

30. Praxedes, S. C., DaMatta, F. M., Loureiro, M. E., Ferrão, M. A. G. \& Cordeiro, A. T. Effects of long-term soil drought on photosynthesis and carbohydrate metabolism in mature robusta coffee (Coffea canephora Pierre var. kouillou) leaves. Environ. Exper. Bot. 56, 263-273 (2006).

31. Souza, B. P., Martinez, H. E. P., Carvalho, F. P., Loureiro, M. E. \& Sturião, W. P. Gas exchanges and chlorophyll fluorescence of young coffee plants submitted to water and nitrogen stresses. J. Plant Nutr. 43, 2455-2465 (2020).

32. Jedmowski, C., Ashoub, A. \& Brüggemann, W. Reactions of Egyptian landraces of Hordeum vulgare and Sorghum bicolor to drought stress, evaluated by the OJIP fluorescence transient analysis. Acta Physiol. Plant 35, 345-354 (2013).

33. Lata, C. \& Prasad, M. Role of DREBs in regulation of abiotic stress responses in plants. J. Exp. Bot. 62, 4731-4748 (2011).

34. Niu, X. et al. Identification of wheat DREB genes and functional characterization of TaDREB3 in response to abiotic stresses. Gene 740, 144514 (2020).

35. Cao, U., Li, K., Li, Y., Zhao, X. \& Wan, L. MYB transcription factors as regulators of secondary metabolism in plants. Biology 9,61 (2020).

36. Baldoni, E., Genga, A. \& Cominelli, E. Plant MYB transcription factors: Their role in drought response mechanisms. Int. J. Mol. Sci. 16, 15811-15851 (2015).

37. Vorwerk, S. et al. EDR2 negatively regulates salicylic acid-based defenses and cell death during powdery mildew infections of Arabidopsis thaliana. BMC Plant Biol. 7, 35 (2007). 
38. Priya, R. et al. Exploring the codon patterns between CCD and NCED genes among different plant species. Comput. Biol. Med. 114, 103449 (2019).

39. Asad, M. A. U. et al. Abiotic stresses intervene with ABA signaling to induce destructive metabolic pathways leading to death: Premature leaf senescence in plants. Int. J. Mol. Sci. 20, 256 (2019).

40. Khodambashi, M., Shiran, B. \& Gharaghanipour, N. Differential expression of CA7 and NCED genes in common bean genotypes under drought stress. J. Agric. Sci. Technol. 15, 1491-1499 (2013).

41. Abid, G. et al. Effect of drought stress on chlorophyll fluorescence, antioxidant enzyme activities and gene expression patterns in faba bean (Vicia fabaL.). Arch. Agron. Soil Sci. 63, 536-552 (2017).

42. Dittrich, M. et al. The role of Arabidopsis ABA receptors from the PYR/PYL/RCAR family in stomatal acclimation and closure signal integration. Nat. Plants 5, 1002-1011 (2019).

43. Park, S. Y. et al. Abscisic acid inhibits PP2Cs via the PYR/PYL family of ABA-binding START proteins. Science 324, 1068-1071 (2009).

44. Noctor, G., Mhamdi, A. \& Foyer, C. H. The roles of reactive oxygen metabolism in drought: not so cut and dried. Plant Physiol. 164, 1636-1648 (2014).

45. Pandey, S. et al. Abiotic stress tolerance in plants: Myriad roles of ascorbate peroxidase. Front. Plant Sci. 8, 581 (2017).

46. Santos, T. B. et al. Expression of threegalactinol synthaseisoforms in Coffea arabica L. and accumulation of raffinose and stachyose in response to abiotic stresses. Plant Physiol. Biochem. 49, 441-448 (2011).

47. El Sayed, A. I., Rafudeen, M. S. \& Golldack, D. Physiological aspects of raffinose family oligosaccharides in plants: Protection against abiotic stress. Plant Biol. 16, 1-8 (2013).

48. Yu, Z., Wang, X. \& Zhang, L. Structural and functional dynamics of dehydrins: A plant protector protein under abiotic stress. Int. J. Mol. Sci. 19, 3420 (2018).

49. Liu, Y., Song, Q., Li, D., Yang, X. \& Li, D. Multifunctional roles of plant dehydrins in response to environmental stresses. Front. Plant Sci. 8, 1018 (2017).

50. Zhu, W. et al. The dehydrin wzy2 promoter from wheat defines its contribution to stress tolerance. Funct. Integr. Genom. 14, 111-125 (2014).

51. Carvalho, A., Mônaco, L. C. \& Fazuoli, L. C. Melhoramento do café XL-Estudos de progênies e híbridos de café Catuaí. Bragantia 38, 202-216 (1979).

52. Rezende, R. M. et al. Agronomic characterization and responses to coffee leaf rust in coffee progenies resistant to the gall nematode Meloidogyne exigua. Semin. Cienc. Agrar. 38, 671-682 (2017).

53. Guimarães, P. T. G. et al. Cafeeiro. In Recomendações Para o uso de Corretivos e Fertilizantes em Minas Gerais: 5 a Aproximação (eds Ribeiro, A. C. et al.) 289-302 (CFSEMG, 1999).

54. R Core Team. R: A language and environment for statistical computing. $R$ Foundation for Statistical Computing, Vienna, Austria (2019). http://www.R-project.org/. Accessed 24 Sep 2020.

55. Mendiburu, F. \& Yaseen, M. Agricolae: Statistical Procedures for Agricultural Research. R package version 1.4.0 (2020). https://myase en208.github.io/agricolae/https://cran.r-project.org/package=agricolae. Accessed 25 Jan 2021.

56. Lê, S., Josse, J. \& Husson, F. FactoMineR: An R package for multivariate analysis. J. Stat. Softw. 25, 1-18 (2008).

57. Schreiber, U. Detection of rapid induction kinetics with a new type of highfrequency modulated chlorophyll fluorometer. Photosynth. Res. 9, 261-272 (1986).

58. Genty, B., Briantais, J.-M. \& Baker, N. R. The relationship between the quantum yield of photosynthetic electron transport and quenching of chlorophyll fluorescence. Biochim. Biophys. Acta. 990, 87-92 (1989).

59. Snel, J. F. H. \& Van Kooten, O. The use of chlorophyll fluorescence and other noninvasive spectroscopic techniques in plant stress physiology. Photosynth. Res. 25, 146-332 (1990).

60. Roháček, K. Chlorophyll fluorescence parameters: The definitions, photosynthetic meaning, and mutual relationships. Photosynthetica 40, 13-29 (2002).

61. Schreiber, U., Bilger, W., Hormann, H. \& Neubauer, C. Chlorophyll fluorescence as a diagnostic tool: Basics andsome aspects of practical relevance. In Photosynthesis: A Comprehensive Treatise (ed. Raghavendra, A. S.) 320-336 (Cambridge University Press, 1998).

62. Ramakers, C., Ruijter, J. M., Deprez, R. H. \& Moorman, A. F. Assumption-free analysis of quantitative real-time polymerase chain reaction (PCR) data. Neurosci. Lett. 339, 62-66 (2003).

63. Barsalobres-Cavallari, C. F., Severino, F. E., Maluf, M. P.\& Maia, I.G. Identification of suitable internal control genes for expression studies inCoffea arabica under different experimental conditions. BMC Mol. Biol. 10, 1 (2009).

\section{Acknowledgements}

The authors thank the Fundação de Amparo à Pesquisa do Estado de Minas Gerais (FAPEMIG), the Coordenação de Aperfeiçoamento de Pessoal de Nível Superior (CAPES), Consórcio Brasileiro de Pesquisa e Desenvolvimento do Café-Consórcio Pesquisa Café and the Conselho Nacional de Desenvolvimento Científico e Tecnológico $(\mathrm{CNPq})$ for the scholarships granted, and the Fundação de Amparo à Pesquisa do Estado de Minas Gerais (FAPEMIG), the Instituto Nacional de Ciência e Tecnologia do Café (INCT-Café) and the Consórcio Brasileiro de Pesquisa e Desenvolvimento do Café-Consórcio Pesquisa Café for the financial support.

\section{Author contributions}

M.O.S.: Formal analysis, Investigation, Data curation, Writing-Original Draft, Visualization. L.S.C.: Conceptualization, Investigation, Data curation, Writing-Original Draft. GRC: Conceptualization, Methodology, Supervision, Project administration, Funding acquisition. C.E.B.: Conceptualization, Methodology. L.F.T.: Investigation, Data curation. D.J.M.V.: Investigation, Data curation. A.C.A.: Conceptualization, Methodology, Resources, Formal analysis Data curation, Writing-Original Draft, Writing-Review \& Editing, Visualization, Supervision, Project administration, Funding acquisition. V.A.S.: Conceptualization, Methodology, Resources, Formal analysis, Data curation, Writing_-Original Draft, Writing-Review \& Editing, Visualization, Supervision, Project administration, Funding acquisition.

\section{Competing interests}

The authors declare no competing interests.

\section{Additional information}

Correspondence and requests for materials should be addressed to V.A.S.

Reprints and permissions information is available at www.nature.com/reprints. 
Publisher's note Springer Nature remains neutral with regard to jurisdictional claims in published maps and institutional affiliations.

(c) (i) Open Access This article is licensed under a Creative Commons Attribution 4.0 International License, which permits use, sharing, adaptation, distribution and reproduction in any medium or format, as long as you give appropriate credit to the original author(s) and the source, provide a link to the Creative Commons licence, and indicate if changes were made. The images or other third party material in this article are included in the article's Creative Commons licence, unless indicated otherwise in a credit line to the material. If material is not included in the article's Creative Commons licence and your intended use is not permitted by statutory regulation or exceeds the permitted use, you will need to obtain permission directly from the copyright holder. To view a copy of this licence, visit http://creativecommons.org/licenses/by/4.0/.

(C) The Author(s) 2021 